\title{
The pattern of loss to follow-up among HIV-infected clients in a tertiary health facility in North Central Nigeria
}

\author{
*Surajudeen O Bello ${ }^{1}$, Efe Abolodje ${ }^{1}$, Esther S Audu², Hassan I Ikrama ${ }^{3}$, Ikekwe Moses Kelechi ${ }^{4}$
}

Sri Lanka Journal of child Health, 2020; 49(2): 170-174

\begin{abstract}
Introduction: Loss to follow-up (LTFU) refers to default from clinic visit more than 3 months after last appointment date. LTFU is a hindrance to successful anti-retroviral therapy (ART) and can potentially worsen the burden of anti-retroviral resistance.
\end{abstract}

Objectives: To identify the prevalence of LTFU and to assess the factors contributing to it.

Method: This is a cross-sectional descriptive study of children and adolescents, aged two years to less than eighteen years, seen from 2007-2017 at Dalhatu Araf Specialist Hospital (DASH), Lafia, Nigeria. Patient clinic register and folders were used to retrieve relevant information such as demographic data, clinical signs and appointments. Data was analysed using SPSS version 20. Categorical and continuous variables were reported in percentages and mean with standard deviation.

Results: A total of 450 patients that were initiated in 2007 were recruited for the study. There were $223(49.6 \%)$ males with a male: female ratio of 1:1. Three hundred and forty one (75.8\%) patients in this study were under five years old. One hundred and eight (24\%) patients were LTFU within the period. There were no significant differences between the median ages and mean weights of males and females in this study. Death did not contribute significantly to LTFU $(p=0.309)$.

${ }^{1}$ Consultant Paediatrician, Department of Paediatrics, ${ }^{2}$ Consultant Medical Microbiologist, Department of Medical Microbiology, ${ }^{3}$ Consultant Public Health Physician, Department of Public Health, ${ }^{4}$ Registrar in Paediatrics, Department of Paediatrics, Dalhatu Araf Specialist Hospital, Lafia Nasarawa State, Nigeria.

*Correspondence: surajudeenbello4@gmail.com

orcid.org/ 0000-0001-8128-4460

(Received on 24 August 2019: Accepted after revision on 18 October 2019)

The authors declare that there are no conflicts of interest

Personal fun ding was used for the project.

Open Access Article published under the Creative

Commons Attribution CC-BY (cC) (i) LY License
Conclusions: The prevalence of loss to follow-up was $24 \%$ in this study while the death prevalence was $3.8 \%$. Three quarter of subjects in this study were under five years of age.

DOI: http://dx.doi.org/10.4038/sljch.v49i2.8966

(Key words: Adolescents, children, HIV - infected, loss to follow up, pattern, health facility)

\section{Introduction}

Nigeria currently has the greatest burden of paediatric human immunodeficiency virus (HIV) infection in the world ${ }^{1}$. The Joint United Nations Programme on HIV/AIDS (UNAIDS) 90-90-90 agenda aims at $90 \%$ of people knowing their HIV status, $90 \%$ of those whose status is known being on antiretroviral therapy (ART) and $90 \%$ of those on ART achieving viral suppression by $2020^{2}$. This agenda is being hindered by issues relating to client retention from loss to follow up (LTFU) ${ }^{3}$. LTFU is a challenge to client retention and is said to occur when a child on 3 monthly visits has defaulted clinic for more than ninety days after the last appointment ${ }^{3}$.

A retrospective cohort study among pre-ART adult Nigerians reported a $74.9 \% \mathrm{LTFU}^{4}$. Another study on ascertaining level of retention among adults on HIV care found $34.9 \%$ LTFU among their subjects $^{5}$. A study in Tanzania, one of the few studies among children, reported $34 \%$ LTFU $^{3}$. The only Nigerian study on the subject was by Ojeniran et $a l$. at the Massey street children Hospital in Lagos and it reported a $16 \%$ LFTU prevalence in a 7 year retrospective cohort ${ }^{6}$. This study is aimed at filling this knowledge gap of knowing the extent of LFTU among Nigerian children.

\section{Objectives}

\section{General objective}

To determine the prevalence and contributors to LTFU among HIV infected children and adolescents attending the ART clinic at the Dalhatu Araf Specialist Hospital (DASH), Lafia, Nigeria.

\section{Specific objectives}

1. To determine the prevalence of LTFU among children receiving ART at DASH

2. To assess the death burden among children accessing ART care at DASH 


\section{Method}

Study design: A cross-sectional descriptive study among children accessing ART care at DASH

Study site: The Special Treatment Clinic of the Paediatric Antiretroviral Clinic, DASH, Lafia, Nigeria. The site is supported by the Institute of Human Virology (IHVN), Nigeria. The clinic operates twice weekly and is run by a Consultant Paediatrician and five residents supported by nurses, pharmacists, laboratory scientists, care and support, monitoring and evaluation officers, adherent counselors and tracking officers etc. Lafia is the capital of Nasarawa State. The state shares boundaries with Benue, Taraba, Plateau, Kaduna, FCT and Kogi states.

Study population: Children, aged 2 years to less than 18 years, attending the Paediatric Antiretroviral Clinic, DASH, Lafia, Nigeria, as at December 2007 had their records studied between this period and December 2017 i.e. December 2007 - November 2017.

Sample size: This was calculated using the formula, $\mathrm{n}=\frac{\mathrm{Z}^{2} \mathrm{pq}}{\mathrm{d}^{2}}$, where $\mathrm{n}=$ sample size calculated, $\mathrm{p}$ is the prevalence at $34 \%{ }^{3}, q=1-p, Z=$ standard deviate at $95 \%$ confidence level $=1.96, \mathrm{~d}=$ level of precision at $5 \%$.

$\mathrm{n}==\frac{1.96^{2} \times 0.34 \times 0.66}{.05^{2}}$

$\mathrm{n}=344.8$

450 were recruited for this study.

Sampling technique: Systematic sampling was used to select the 450 subjects from the list of paediatric patients accessing ART care at DASH provided by the medical records monitoring and evaluation officer. A sampling frame was derived by dividing the total number of clients that met the criteria $(1,400)$ by 450 , which is the sample size, to get 3 . Simple random sampling was then used to pick the first subject, after which every third subject was selected until the sample size of 450 was attained.

Inclusion Criteria: All children, aged 2 years to less than 18 years, attending the Paediatric/ Adolescent ART clinic at DASH within the study period.

Exclusion Criteria: Children whose records are not found and those with incomplete records having fulfilled the inclusion criteria

Recruitment procedure: The paediatric antiretroviral clinic records of patients were used to recruit subjects that met the criteria. Their folders were then retrieved from the hospital medical records to get their respective biodata. In this clinic ART was commenced in children only when they were confirmed to be HIV-infected. Confirmation of HIV infection among children less than 18 months old required two positive results from HIV DNA through polymerase chain reaction (PCR) which was done by sending Dried Blood Spot (DBS) sample to Jos University Teaching Hospital (JUTH). On the other hand, children aged 18 months and above were diagnosed using a double rapid HIV antibody test with Determine and STATPAK in a serial algorithm and confirmed with a third kit "Unigold", when there was a stalemate. Interviewer administered questionnaire was used to record the biodata and other possible risks identified and recorded in the Proforma.

Ethical issues: Ethics Approval was obtained from the Hospital Research Ethics Committee (REC) of DASH. The information obtained from the participant records and folders was treated with strict confidentiality and was stored as code in a pass worded computer, the raw data being stored and locked up in a well secured locker.

Data analysis: Data were entered into a Microsoft Excel sheet with the variables coded before transferring into a statistical package for social sciences (SPSS) version 20. Categorical variables were presented with tables of frequency distribution. Mean and standard deviation as well as median and inter-quartile range of continuous variables were calculated. The association between two categorical variables was calculated using Chi square. The significant $p$ value was $p<0.05$.

\section{Results}

Demographic characteristics of the population

Of the 450 participants recruited for this study, $49.6 \%$ were male with a male: female ratio of $1: 1$. Children under the age of five years accounted for more than three-quarter of the study population (Table 1).

Table I

Demographic characteristics of the population

\begin{tabular}{|c|c|}
\hline Chorentaristi & Froolonow $(0 /)$ \\
\hline Sex & \\
\hline Male & $223(49.6)$ \\
\hline Female & $227(50.4)$ \\
\hline Age (years) & \\
\hline$<5$ & $341(75.8)$ \\
\hline $5-10$ & $65(14.4)$ \\
\hline$>10$ & $44(09.8)$ \\
\hline
\end{tabular}

Distribution of mean/ median age and weight across gender

There was no significant difference between the median age and mean weight for males and females as shown in Table 2. 
Table 2

Distribution of median age and mean weight across gender

\begin{tabular}{|l|c|c|}
\hline Age (months) & Median (IQR) & p-value \\
\hline Male & $23.0(12.0-48.0)$ & 0.504 \\
Female & $24.0(12.0-42.5)$ & \\
\hline Weight (kg) & Mean \pm SD & p-value \\
\hline Male & $14.37 \pm 8.42$ & 0.843 \\
Female & $14.07 \pm 9.16$ & \\
\hline
\end{tabular}

\section{Distribution of patient retention in care}

One hundred and eight (24\%) patients were LTFU in this study. Although there are $62(57.4 \%)$ males LTFU compared to $46(42.6 \%)$ females, this difference was not significant $(p=0.309)$. More than two-third of our clients remained in care after a decade. This is shown in Table 3.

Table 3: Distribution of patients' retention in care

\begin{tabular}{|l|c|c|c|c|c|}
\hline \multicolumn{1}{|c|}{ Characteristic } & Male & Female & Total & Chi square & p-value \\
\hline Lost to follow up - n (\%) & $62(57.4)$ & $46(42.6)$ & $108(24.0)$ & 1.035 & 0.309 \\
\hline Death - n (\%) & $10(58.8)$ & $07(41.2)$ & $17(03.8)$ & - & - \\
\hline Retention in care - n (\%) & $151(46.5)$ & $174(53.5)$ & $325(72.2)$ & - & - \\
\hline Total - n (\%) & $223(49.6)$ & $227(50.4)$ & $450(100.0)$ & - & - \\
\hline
\end{tabular}

\section{Discussion}

There were more children under the age of five years recruited in this study. The median age of females was higher than that of males whereas the mean weight of males was higher than that of females. Percentage of children LTFU was $24 \%$, which is less than the $37.6 \%$ reported by Massavon et al in a larger multi-centre study in Uganda ${ }^{7}$. Ojwang and colleagues also reported 57\% among the adult population in Kenya ${ }^{8}$. The difference in sample size and location may account for the disparity. The finding in this study is also lower compared to the $36 \%$ reported by Chandiwana et $a l^{9}$ among South African children. Even though the median age in the study (21.5 months) is comparable to the 23 months in the present study, the longer years of follow up (10 years) in this study compared with the 3.3 years as well as the lower sample size of 135 compared with 450 in the present study could explain the difference. The finding in this study is higher than the $8.4 \%$ reported in a study by Kranzer et al ${ }^{10}$ in Zimbabwe. Similarly, Saka et $a l^{11}$ in Togo found a lower prevalence of $7.3 \%$. The disparity with our study may be due to the variation in retention time which is ten years in the current study. The finding here is also more than the $17.2 \%$ reported by Saumu et al ${ }^{12}$ in Kenya. The difference in median age (about 2 years compared with 10 years in the Kenya study) may explain the observed disparity. The later study also used a smaller sample size (261) compared to the current study. Difference in the study population may also explain the difference noticed.

Deaths recorded in this study was $3.8 \%$ which is lower than the $5.3 \%$ reported in $\mathrm{Uganda}^{7}$. It is lower than the $5.9 \%$ reported in Nigeria across the six geo-political zones among the adults ${ }^{13}$. Similarly, it is even much lower than the $10.2 \%$ reported in South-Eastern Nigeria among adult patients which may be responsible for the contrast noticed $^{14}$. The possibility of differential care that is largely in favour of children may also be a factor.
Some of the patient's LTFU in the current study might have died without the awareness of the tracking team. A study in Makurdi among children however found as high as $10.9 \%$ deaths in their cohorts $^{15}$. Most of their patients were older than five years with a median age of 5.6 years compared to the two years in the present study.

Approximately $72.2 \%$ of our clients remained in care after ten years on treatment. This is lower than the $89.7 \%$ and $80.9 \%$ reported in Makurdi among children $0-15$ years after six months and twelve months respectively ${ }^{15}$. This suggests that patient retention in care reduces with increasing years of follow up, probably due to apathy, death or relocation.

\section{Conclusions}

The prevalence of loss to follow-up was $24 \%$ in this study while the death prevalence was $3.8 \%$. Three quarter of subjects in this study were under five years of age.

\section{Acknowledgements}

We acknowledge Mr. Yahaya Ozegya and Dr. Mrs. Anderson Immaculata for their technical support in retrieving patient's medical records.

\section{References}

1. Ogunbosi BO, Oladokun RE, Brown BJ, Osinusi KI. Prevalence and clinical pattern of Paediatric HIV infection at the University College Hospital, Ibadan, Nigeria: a prospective cross-sectional study. Italian Journal of Pediatrics 2011; 37: $29-34$.

https://doi.org/10.1186/1824-7288-37-29

PMid: 21679464 PMCid: PMC3133997

2. Abrams EJ, Strasser S. 90-90-90-Charting a steady course to end the paediatric HIV epidemic. Journal of the 
International AIDS Society 2015; 18(suppl. 6):20296. https://doi.org/10.7448/IAS.18.7.20296

3. Mccormick NM, Li N, Sando D, Muya A, Manji KP, Kisenge R, et al. Risk factors of loss to follow up among HIV positive paediatric patients in Dar es Salaam, Tanzania. Journal of Acquired Immune Deficiency Syndromes 2015; 70(3): e73e83.

https://doi.org/10.1097/QAI.00000000000 00782

PMid: 26247894 PMCid: PMC4650894

4. Agolory SG, Auld AF, Odafe S, Shiraishi RW, Dokubo EK, Swaminathan N, et al. High rates of loss to follow-up during the first year of pre-antiretroviral therapy for HIV patients at sites providing pre-ART care in Nigeria, 2004-2012. Plos One 2017; 12(9): e0183823.

https://doi.org/10.1371/journal.pone.0183 823

PMid: 28863160 PMCid: PMC5581182

5. Fleishman JA, Yehia BR, Moore RD, Korthuis PT, Gebo KA, HIV Research Network. Establishment, retention and loss to follow up in outpatient HIV care. Journal of Acquired Immune Deficiency Syndromes 2012; 60(3): 249-59.

https://doi.org/10.1097/QAI.0b013e31825

8c696

PMid: 22531758 PMCid: PMC3383913

6. Ojeniran MA, Emokpae A, Mabogunje C, Akintan P, Hoshen M, Weiss R. How are children faring in Nigeria? A 7 year retrospective study of children enrolled in HIV care. BMC Paediatrics 2015; 15: 8792.

https://doi.org/10.1186/s12887-015-04059

PMid: 26198439 PMCid: PMC4510895

7. Massavon $\mathrm{W}$, Lundin $\mathrm{R}$, Costenaro $\mathrm{P}$, Penazzato M, Namisi PC, Resty I, et al. Attrition and loss to follow-up among children and adolescents in a community home-based care HIV programme in Uganda. Pediatrics \& Therapeutics 2013; 3: 5 .

8. Ojwang VO, Penner J, Blat C, Agot K, Bukusi EA, Cohen CR. Loss to follow-up among youths accessing outpatient HIV care and treatment services in Kisumu, Kenya. AIDS Care 2016; 28(4): 500-7. https://doi.org/10.1186/s12887-015-04059

PMid: 26198439 PMCid:PMC4510895

9. Chandiwana N, Sawry S, Chersich M, Kachingwe E, Makhathini B, Fairlie L. High loss to follow up of children on antiretroviral treatment in a primary care HIV clinic in Johannesburg, South Africa. Medicine (Baltimore) 2018; 97(29):12-6. https://doi.org/10.1097/MD.00000000000 10901

PMid: 30024494 PMCid: PMC6086461

10. Kranzer K, Bradley J, Musaazi J, Nyathi $\mathrm{M}$, Gunguwo H, Ndebele W, et al. Loss to follow-up among children and adolescents growing up with HIV infection : age really matters. Journal of the International AIDS Society 2017; 20(1):21737.

https://doi.org/10.7448/IAS.20.1.21737

PMid: 28715158 PMCid: PMC5577636

11. Saka B, Landoh DE, Patassi A, d'Almeida $\mathrm{S}$, Singo A, Gessner BD, et al. Loss of HIV-infected patients on potent antiretroviral therapy programs in Togo: risk factors and the fate of these patients. Pan African Medical Journal 2013; 15: 35-41.

https://doi.org/10.11604/pamj.2013.15.35. 2198

PMid: 24009811 PMCid: PMC3758855

12. Saumu WM, Maleche-Obimbo E, Irimu G, Kumar R, Gichihi C, Karau B. Predictors of loss to follow up among children attending HIV clinic in a hospital in rural Kenya. Pan African Medical Journal 2019; 32:216-9.

https://doi.org/10.11604/pamj.2019.32.21

6.18310

PMid: 31312327 PMCid: PMC6620067

13. Agolory SG, Auld AF, Odafe S, Shiraishi RW, Dokubo EK, Swaminathan M, et al. High rates of loss to follow-up during the first year of pre-antiretroviral therapy for HIV patients at sites providing pre- ART care in Nigeria. PLoS One 2017; 12(9):18-32.

https://doi.org/10.1371/journal.pone.0183 823

PMid: 28863160 PMCid: PMC5581182 
14. Eguzo KN, Lawal AK, Umezurike CC, Eseigbe CE. Predictors of loss to followup among HIV-infected patients in a rural South Eastern Nigeria hospital: A 5 year retrospective cohort study. Annals of Medical and Health Science Research 2015; 5(6): 373-8.

https://doi.org/10.4103/2141-9248.177988

PMid: 27057373 PMCid: PMC4804646
15. Anigilaje EA, Aderibigbe SA. Mortality in a cohort of HIV-infected children: A 12month outcome of antiretroviral therapy in Makurdi, Nigeria. Advances in Medicine 2018; 2018: 6409134.

https://doi.org/10.1155/2018/6409134

PMid: 30018988 PMCid: PMC6029505 